University of Nebraska - Lincoln

DigitalCommons@University of Nebraska - Lincoln

USDA National Wildlife Research Center - Staff Publications
U.S. Department of Agriculture: Animal and Plant Health Inspection Service

2010

\title{
Experimental Exposure of Swallow Bugs (Hemiptera: Cimicidae) to West Nile Virus
}

\author{
Paul T. Oesterle \\ National Wildlife Research Center, paul.t.oesterle@aphis.usda.gov \\ Nicole M. Nemeth \\ Colorado State University, nnemeth@colostate.edu \\ Paul Doherty \\ Colorado State University \\ Robert McLean \\ National Wildlife Research Center \\ Larry Clark
}

USDA/APHIS/WS National Wildlife Research Center, clark@metis4u.net

Follow this and additional works at: https://digitalcommons.unl.edu/icwdm_usdanwrc

Oesterle, Paul T.; Nemeth, Nicole M.; Doherty, Paul; McLean, Robert; and Clark, Larry, "Experimental Exposure of Swallow Bugs (Hemiptera: Cimicidae) to West Nile Virus" (2010). USDA National Wildlife Research Center - Staff Publications. 1279.

https://digitalcommons.unl.edu/icwdm_usdanwrc/1279

This Article is brought to you for free and open access by the U.S. Department of Agriculture: Animal and Plant Health Inspection Service at DigitalCommons@University of Nebraska - Lincoln. It has been accepted for inclusion in USDA National Wildlife Research Center - Staff Publications by an authorized administrator of DigitalCommons@University of Nebraska - Lincoln. 


\title{
Experimental Exposure of Swallow Bugs (Hemiptera: Cimicidae) to West Nile Virus
}

\author{
PAUL OESTERLE,${ }^{1,2,3}$ NICOLE NEMETH,${ }^{4}$ PAUL DOHERTY,${ }^{2}$ ROBERT MCLEAN,${ }^{1}$ \\ AND LARRY CLARK ${ }^{1}$
}

J. Med. Entomol. 47(5): 897-901 (2010); DOI: 10.1603/ME10039

\begin{abstract}
The cliff swallow (Petrochelidon pyrrhonota, Vieillot) could potentially play an important role in the transmission of West Nile virus (WNV) because of its breeding ecology, reservoir competence status, and potentially high natural exposure rates. These birds nest in colonies and their nests are occupied year round by swallow bugs (Oeciacus vicarius, Hovarth), hematophagus ectoparasites that feed primarily on cliff swallows. Swallow bugs are most likely exposed to WNV while feeding on infectious blood of cliff swallows and, thus, if competent vectors, could contribute to initiation and maintenance of seasonal WNV transmission. In addition, swallow bugs remain within nests year round and, therefore, if persistently infected and competent vectors, they could provide an overwintering mechanism for WNV. We tested the hypothesis that swallow bugs become infected with WNV through direct abdominal inoculation or ingestion of infectious blood meals. We observed that swallow bugs did not maintain or amplify WNV, and infectious virus titers within bugs declined over $15 \mathrm{~d}$ postexposure. These results suggest that swallow bugs may not be competent vectors of $\mathrm{WNV}$, and therefore are unlikely to play a significant role in transmission.
\end{abstract}

KEY WORDS cliff swallow, Oeciacus vicarius, Petrochelidon pyrrhonota, swallow bug, West Nile virus

Swallow bugs (Oeciacus vicarius, Hovarth) are wingless hemimetabolous ectoparasites for which the blood of cliff swallows (Petrochelidon pyrrhonota, Vieillot) is the primary food source. Swallow bugs reside within and use cliff swallow mud nests as a substrate for oviposition (Loye 1985) and move freely within and between nest colonies, although the latter only occurs while attached to a host (Brown and Brown 2005). The geographic distribution of cliff swallows and swallow bugs overlaps with the expanding endemic range of West Nile virus (WNV; family Flaviviridae, genus Flavivirus) in North America. Additionally, cliff swallows develop West Nile viremia titers sufficient to infect mosquitoes (Oesterle et al. 2009) and have a high rate of exposure to the virus in some geographic areas (our unpublished data).

Although the transmission cycle of WNV involves birds as the primary reservoir host and mosquitoes as the primary vector (Work et al. 1955, Hayes 1989),

${ }^{1}$ National Wildlife Research Center (United States Department of Agriculture/Animal and Plant Health Inspection Service/Wildlife Services), 4101 Laporte Avenue, Fort Collins, CO 80521.

${ }^{2}$ Colorado State University, Department of Fish, Wildlife, and Conservation Biology, 109 Wagar Building, Campus Delivery 1474, Fort Collins, CO 80523.

${ }^{3}$ Corresponding author: National Wildlife Research Center (United States Department of Agriculture/Animal and Plant Health Inspection Service/Wildlife Services), 4101 Laporte Avenue, Fort Collins, CO 80521 (e-mail: paul.t.oesterle@aphis.usda.gov).

${ }^{4}$ Colorado State University, Department of Biomedical Sciences, 3801 West Rampart Road, Fort Collins, CO 80523. some aspects of transmission, such as nontraditional infection routes and overwintering mechanism(s), remain unknown (Dohm and Turell 2001, Reisen et al. 2006). For example, a nonmosquito vector, the seabird soft tick (Carios capensis, Neumann), transmitted WNV to ducklings in an experimental setting (Hutcheson et al. 2005). Furthermore, evidence for overwintering of WNV in mosquitoes has been limited (Nasci et al. 2001, Farajollahi et al. 2005, Bolling et al. 2007), supporting potential alternative means of overwintering such as virus persistence within vectors or hosts. Swallow bugs could potentially serve as WNV vectors and provide an overwintering mechanism because they are known virus vectors, both transmitting and overwintering Buggy Creek virus (family Togaviridae, genus Alphavirus), which infects cliff swallows and other birds when fed upon by infectious swallow bugs (Rush et al. 1980, Hopla et al. 1993, Brown et al. 2009). Swallow bugs and other nontraditional vectors may contribute to $\mathrm{WNV}$ maintenance throughout winter periods and subsequently reinitiate avian-mosquito amplification cycles.

Given the parasitic nature of swallow bugs and WNV reservoir competence of cliff swallows (Oesterle et al. 2009), swallow bugs most likely ingest infectious WNV blood meals when feeding on viremic cliff swallows. However, limited, yet conflicting information exists regarding the ability of swallow bugs to become infected with and transmit WNV; Sixl et al. (1989) demonstrated WNV seroconversion in mice in 
the presence of swallow bugs, whereas Oesterle et al. (2010) failed to document WNV transmission from swallow bugs to cliff swallow nestlings in an experimental trial. To clarify the potential role of swallow bugs as WNV vectors in nature, we exposed swallow bugs to WNV by direct abdominal inoculation and by feeding them WNV-spiked blood. The objectives of the current study were to assess whether swallow bugs become infected with WNV, and whether WNV amplifies and persists within these parasites.

\section{Methods and Materials}

Collection of Swallow Bugs. Before the initiation of the cliff swallow breeding season, 10 swallow buginfested cliff swallow nests were collected from a colony near Fort Collins, Colorado, in March 2007. Nests were individually placed in 2-liter plastic storage containers and transported to the United States Department of Agriculture National Wildlife Research Center (Fort Collins, CO). Within $24 \mathrm{~h}$, swallow bugs were removed from nests using Berlese funnels (Bioquip, Rancho Dominguez, CA) and transferred to a 4-liter glass beaker. Seed germination paper (Anchor Paper, Saint Paul, MN) was folded accordion style and placed in the beaker as a substrate for the swallow bugs; the beakers were covered with a fine mesh cloth to prevent escape of swallow bugs. The beakers were then placed in an insect growth chamber (BioCold Environmental, Fenton, MO) with environmental parameters of $12^{\circ} \mathrm{C}, 70 \%$ humidity, and 10 -h photoperiod. Temperature and photoperiod were gradually increased to $27^{\circ} \mathrm{C}$ and $14 \mathrm{~h}$ of light per day over 3 mo to bring swallow bugs out of diapause. Swallow bugs were not allowed to feed during this period.

Inoculation of Swallow Bugs. Only swallow bugs at later developmental stages (i.e., fourth instar to adult; Usinger 1966) were inoculated. The procedure involved immobilization of swallow bugs by chilling in a glass petri dish over wet ice and then placing them in a dorsal position. Then, by viewing through a dissecting microscope, a glass needle was inserted into the abdomen, followed by gradual, but steady injection of the $\approx 0.5-2 \mu \mathrm{l}$ of WNV inoculum.

Injection of swallow bugs was accomplished through use of a $60-\mathrm{ml}$ syringe, glass needle, and polyethylene tubing $(60 \mathrm{~cm} \mathrm{~L}, 0.16 \mathrm{~cm} \mathrm{D})$ to connect the syringe and needle. Glass needles were made using a capillary tube (inner diameter $1.1 \mathrm{~mm}$ ) and micropipette puller (Narishige International, East Meadow, $\mathrm{NY}$ ); the tip was beveled $\left(40^{\circ}\right)$ with a microelectrode beveler (Sutter Instrument, Novato, CA). The inoculum was first drawn into the needle and then injected into the swallow bug by pressure created in the syringe. The quantity of inoculum was approximated by measuring the distance the column of liquid traveled during the injection $(1 \mathrm{~mm} \approx 1 \mu \mathrm{l})$.

Each of five injection trials involved a total of $30-50$ swallow bugs; $20-30$ were injected intra-abdominally with WNV NY99 strain 4132 ( $10^{5.6}$ plaque-forming units $[\mathrm{PFU}] / \mathrm{ml}$, diluted in BA-1 medium), whereas the remaining 10-20 were injected with nonvirus- containing BA-1 medium (M199, 0.05 M Tris, $\mathrm{pH}$ 7.6, $1 \%$ bovine serum albumin, $0.35 \mathrm{~g} / \mathrm{L}$ sodium bicarbonate, $100 \mathrm{U} / \mathrm{ml}$ penicillin, $100 \mu \mathrm{g} / \mathrm{ml}$ streptomycin, and $1 \mu \mathrm{g} / \mathrm{ml}$ amphotericin B). One-half of the swallow bugs in each group were killed within $3 \mathrm{~h}$ of injection (i.e., $0 \mathrm{~d}$ postexposure [DPE]), whereas the remaining swallow bugs were killed at one of the following time points: $3,6,9,12,15$ DPE.

Oral Exposure of Swallow Bugs. Swallow bugs were orally exposed to $\mathrm{WNV}$ by providing a blood meal infused with WNV. Blood was collected from WNVseronegative chickens, placed into tubes containing sodium heparin, and then spiked with WNV (same strain as used for injection experiments) for an approximate viral titer of either $10^{3.7}$ or $10^{8.1} \mathrm{PFU} / \mathrm{ml}$ blood, whereas nonvirus-containing BA-1 medium was used for sham-inoculated controls. For feeding trials, blood was placed in 33-mm membrane feeders (Lillie Glassblowers, Smyrna, GA); stretched Parafilm (ALCAN, Neenah, WI) was used as a membrane, and warm water $\left(40^{\circ} \mathrm{C}\right)$ was circulated through the water jacket of the feeder.

At each of four blood-feeding trials, $\approx 5,000-10,000$ swallow bugs were divided between two beakers, with $\approx 75 \%$ of the swallow bugs placed in the $\mathrm{WNV}$-exposed beaker, and the remaining $\approx 25 \%$ placed in the control beaker. Seed germination paper was provided as a substrate; the paper allowed the swallow bugs to access the top of the container. Mesh was secured over the beakers with a rubber band. The blood-containing membrane feeders (one spiked with WNV, and the other with BA-1 medium) were placed directly across the mesh of the beakers for direct contact between the Parafilm and the mesh. The feeders were supported by a clamp and stand.

Feeding apparatuses were in place for 2-3 $\mathrm{h}$, after which engorged swallow bugs were collected and nonengorged were discarded. A portion $(n=20-40)$ of the engorged swallow bugs was processed immediately (0 DPE), and the remainder was placed in a clean beaker with clean substrate and maintained for sampling at later time points. These remaining swallow bugs were sampled between 1 and 15 DPE (20-40 swallow bugs per time point).

Sample Processing and Testing. Inocula and blood meals were aliquotted before feeding for later testing. Blood aliquots $(0.2 \mathrm{ml})$ were placed in serum separator tubes (Microtainer Benton Dickinson and Company, Franklin Lakes, NJ) and centrifuged at 10,000 $\times$ $g$ for 5 min within $1 \mathrm{~h}$ of collection to separate plasma from packed cells. The inocula and plasma aliquots were frozen to $-80^{\circ} \mathrm{C}$.

After recording developmental stage (first instar through adult), engorged swallow bugs were individually processed in 2-ml microcentrifuge tubes (Fisher Scientific, Pittsburgh, PA) with $500 \mu$ l of BA-1 medium and a copper BB ( $4.5 \mathrm{~mm}$; Crosman, East Bloomfield, NY). Tubes were placed in chilled racks (TissueLyser Adapter Set; Qiagen, Valencia, CA), agitated for 10 min at 25 Hertz using a Mixer Mill homogenizer (model MM 301; Retsch, Newton, PA), centrifuged at $10,000 \times g$ for $3 \mathrm{~min}$, and frozen to $-80^{\circ} \mathrm{C}$. 


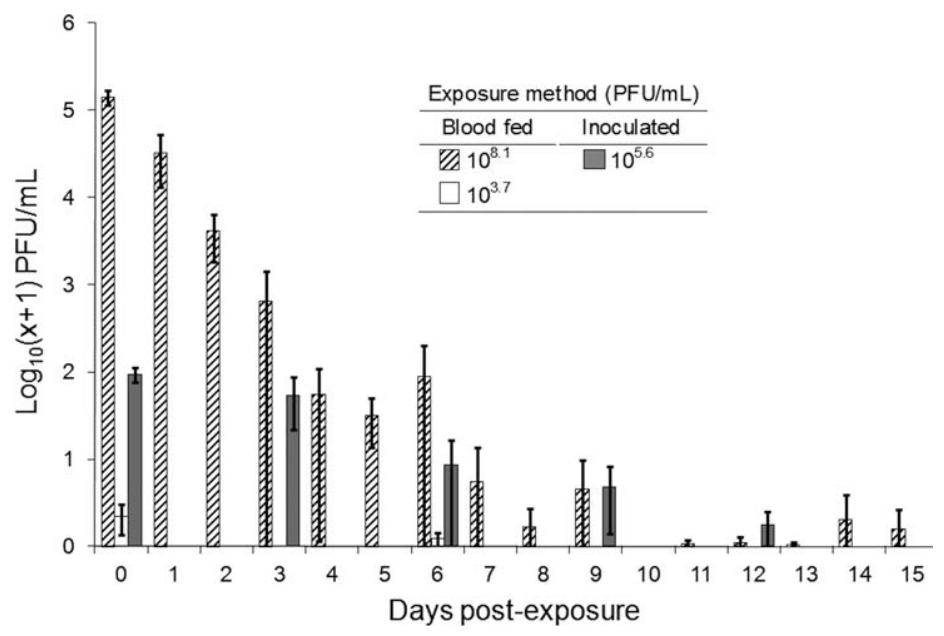

Fig. 1. Detectable virus titers in swallow bugs exposed to one of three WNV titers (blood meals at $10^{3.7}$ and $10^{8.1} \mathrm{PFU} / \mathrm{ml}$, and needle inoculation with $10^{5.6} \mathrm{PFU} / \mathrm{ml}$ ) by two methods. Negative control swallow bugs (inoculated with BA-1 or fed blood infused with BA-1 only) did not show detectable virus. The $95 \%$ confidence intervals are shown.

Aliquots of inocula and blood meals and individual swallow bugs were tested by Vero cell plaque assay (Komar et al. 2003). Briefly, Vero cell monolayers in 6-well plates were inoculated in duplicate with $0.1 \mathrm{ml}$ of sample/well. The plates were incubated for $1 \mathrm{~h}$ at $37^{\circ} \mathrm{C}$, and then cells were overlaid with $3 \mathrm{ml} /$ well $0.5 \%$ agarose in minimum essential medium supplemented with $2 \%$ fetal bovine serum and antibiotics. Two days later, cells were overlaid with a second 3-ml overlay containing $0.004 \%$ neutral red dye. Viral plaques were counted on the third and fourth days of incubation. The minimum titer of WNV for swallow bugs was $10^{0.4} \mathrm{PFU} / \mathrm{ml}$ swallow bug homogenate; titers below this threshold were considered zero.

Analysis. Before analysis, viral titers of swallow bugs, blood meals, and injected inocula were log transformed $\left(\log _{10}[x+1]\right)$. Daily mean titers and confidence interval were calculated for each group of exposed swallow bugs (Fig. 1).

\section{Results}

All needle-inoculated swallow bugs tested WNV positive at 0 DPE (mean $10^{1.8} \mathrm{PFU} /$ swallow bug). The percentage of swallow bugs with detectable virus declined from $100 \%(n=60)$ to $0 \%(0 / 12)$ by $15 \mathrm{DPE}$ (Fig. 1; Table 1). None of the swallow bugs that were sham inoculated with BA-1 medium tested WNV positive.

The results from the blood-fed swallow bugs (approximate feeding rate $5-10 \%$ ) varied greatly depending on the titer of the blood meal provided (Table 1). Among swallow bugs that fed on blood containing a low WNV titer $\left(10^{3.7} \mathrm{PFU} / \mathrm{ml}\right.$ plasma), $21 \%$ (8 of 37 ) had detectable WNV at 0 DPE (mean titer $10^{0.35} \mathrm{PFU} /$ swallow bug, range $0-10^{0.8} \mathrm{PFU} / \mathrm{ml}$ ). Among all swallow bugs sampled at subsequent time points $(3,6,9,12$, and 15 DPE), only one had detectable virus (6 DPE; Fig. 1). Swallow bugs that fed on blood with a high WNV titer $\left(10^{8.1} \mathrm{PFU} / \mathrm{ml}\right.$ plasma $)$ had a higher infection rate and mean viral titers, and virus persisted for a longer period postfeeding. Between 0 and 15 DPE, the percentage of swallow bugs with detectable virus and mean viral titers declined from $100 \%(n=40)$ to $5 \%(2 / 40)$, and $10^{5.2}$ to $10^{0.2} \mathrm{PFU} /$ swallow bug, respectively (Fig. 1). No swallow bugs that fed on blood infused with BA-1 (e.g., no virus) tested WNV positive.

\section{Discussion}

The unique interactive ecologies of swallow bugs and cliff swallows create an environment conducive to arbovirus transmission; for example, these species are integral to the ecology of Buggy Creek virus (Strauss

Table 1. Results of virus isolation of swallow bugs exposed to varying levels of WNV $\left(10^{3.7}, 10^{5.6}, 10^{8.1} \mathrm{PFU} / \mathrm{ml}\right)$ by either needle inoculation or blood meal ingestion

\begin{tabular}{|c|c|c|c|c|c|c|c|c|c|c|c|c|c|c|c|c|c|c|}
\hline \multicolumn{3}{|c|}{ Swallow bugs exposed } & \multicolumn{16}{|c|}{ No. positive/tested (day postexposure) } \\
\hline Method & $\mathrm{PFU} / \mathrm{ml}$ & $\begin{array}{c}\text { No. } \\
\text { exposed }\end{array}$ & 0 & 1 & 2 & 3 & 4 & 5 & 6 & 7 & 8 & 9 & 10 & 11 & 12 & 13 & 14 & 15 \\
\hline Injection $^{a}$ & $10^{5.6}$ & 120 & $60 / 60$ & - & - & $9 / 14$ & - & - & $6 / 12$ & - & - & $5 / 12$ & - & - & $3 / 10$ & - & - & $0 / 12$ \\
\hline Blood meal & $10^{3.7}$ & 183 & $8 / 37$ & - & - & $0 / 37$ & - & - & $1 / 37$ & - & - & $0 / 20$ & - & - & $0 / 20$ & - & - & $0 / 32$ \\
\hline Blood meal & $10^{8.1}$ & 622 & $30 / 30$ & $40 / 40$ & $39 / 40$ & $39 / 40$ & $24 / 40$ & $27 / 40$ & $18 / 40$ & $9 / 40$ & $4 / 40$ & $4 / 40$ & $0 / 32$ & $1 / 40$ & $1 / 40$ & $1 / 40$ & $2 / 40$ & $2 / 40$ \\
\hline
\end{tabular}

${ }^{a}$ Data from five separate abdominal injection trials combined. 
and Strauss 1994). The swallow bug is a long-lived, hematophagus, hemimetabolous, wingless parasite that is highly dependent on cliff swallows for sustenance, shelter, and breeding (Loye 1985). There is evidence that these parasites are naturally exposed to $\mathrm{WNV}$, as swallow bugs tested positive for WNV RNA in Colorado in summer and winter of 2003-2004 (our unpublished data). Additionally, Sixl et al. (1989) documented possible WNV transmission to mice via swallow bugs; in this study, mice cohoused with swallow bugs seroconverted to $\mathrm{WNV}$, but whether swallow bugs were the definitive and sole source of infection was unclear.

Various aspects of cliff swallow biology could contribute to the potential ecological interactions among vertebrate host, vector, and virus, thereby warranting examination of this avian species for involvement in arbovirus transmission. Cliff swallows nest synchronously in large colonies (Brown and Brown 1995) often over water, where some mosquito species (e.g., Culex tarsalis) are relatively abundant (Brown and Sethi 2002). These birds are most likely reservoir competent for WNV in nature (average peak viremia of experimentally inoculated swallow was $10^{6.3} \mathrm{PFU} / \mathrm{ml}$ serum; Oesterle et al. 2009), and in 2003, 22\% of cliff swallow nestlings tested oral swab positive for WNV RNA (our unpublished data). In addition, there was a high rate of natural exposure (20-40\%) among freeranging adult cliff swallows in northern Colorado from 2004 to 2007 (our unpublished data). These data indicate that relatively high rates of natural WNV infection occurred among cliff swallows that congregated to breed within several Colorado counties.

As the primary vectors of WNV and numerous other arboviruses, mosquitoes provide a model for dissemination and transmission of virus within the vector. In competent mosquitoes, WNV replicates to moderate titers in the midgut and disseminates to the hemocoel, where it replicates to high titers and then infects the salivary glands, after which virus can be transmitted to naive hosts. Within this system, both virus replication and dissemination within the mosquito are required for transmission (Turell et al. 2001). Results from the current study suggest that swallow bugs are unable to support replication or maintenance of WNV. The viral load in swallow bugs declined rapidly over time, regardless of exposure route or viral titer of the blood meal or injected inoculum, indicating that WNV did not amplify within the swallow bugs. At the high-titer blood meal provided to the swallow bugs (i.e., $10^{8.1}$ $\mathrm{PFU} / \mathrm{ml}$ plasma), only $5 \%$ of blood-fed swallow bugs had detectable WNV after $15 \mathrm{~d}$, and titers in these swallow bugs were minimal (Fig. 1). In contrast, WNV was detected in $71 \%(n=458)$ of Culex spp. mosquitoes 12-15 d after ingestion of a WNV-infectious blood meal containing $10^{7.1-7.2} \mathrm{PFU} / \mathrm{ml} \mathrm{WNV}$ (Turell et al. 2000, 2001; Goddard et al. 2002).

As with most controlled studies, data from the current study should be interpreted with several limitations in mind. First, neither blood feeding from a membrane feeder nor needle inoculation can adequately mimic the complex interplay of circumstances that would result from a hematophagus insect feeding on a WNV-infected cliff swallow. Second, the sample size of swallow bugs in the current study does not compare with that in nature and, therefore, if the probability of a WNV transmission or overwintering event is sufficiently rare, the present experiment may fail to detect it. Third, we did not specifically examine viral dissemination within the swallow bug; however, results from a previous study support the notion that WNV dissemination in swallow bugs is unlikely (Oesterle et al. 2010). Finally, the current study design was aimed at assessing virus replication in bugs that might lead to biological transmission; mechanical transmission of WNV via swallow bugs could potentially occur soon after ingestion of an infectious blood meal and remains a possible means for transmission. However, the virus would not likely remain viable outside of the host or vector for sufficient time to provide an efficient transmission mechanism (Chamberlain and Sudia 1961).

In conclusion, whereas we were unable to implicate swallow bugs in the transmission or overwintering of WNV, further exploration of this concept may be warranted based on lack of knowledge of definitive overwintering mechanisms for WNV and other arboviruses for which seasonal reinitiation of transmission occurs. Additionally, unexplained observations regarding WNV and swallow bugs include apparent WNV infection of mice via swallow bugs (Sixl et al. 1989) and WNV RNA-positive swallow bugs during winter in northern Colorado (our unpublished data). Investigations of WNV dynamics within swallow bugs after ingestion of infectious blood meals using techniques such as immunochemical localization of sites of virus replication, as well as continued testing of fieldcollected swallow bugs, would help further evaluate their possible role in arbovirus transmission.

\section{Acknowledgments}

We thank Jenella Loye for guidance on husbandry of swallow bugs, and Richard Bowen for use of BSL-3 laboratory space. This work was supported by National Institutes of Health Grant 1RO1CI000219-01 (to L.C.), the Centers for Disease Control and Prevention, and the National Wildlife Research Center (United States Department of Agriculture/ Animal and Plant Health Inspection Service/Wildlife Services).

\section{References Cited}

Bolling, B. G., C. G. Moore, S. L. Anderson, C. D. Blair, and B. J. Beaty. 2007. Entomological studies along the Colorado front range during a period of intense West Nile virus activity. J. Am. Mosq. Control Assoc. 23: 37-46.

Brown, C. R., and M. B. Brown. 1995. Cliff swallow (Hurundo pyrrhonota), pp. 1-28. In A. Poole and F. Gill (eds.), The Birds of North America. Academy of Natural Sciences, Philadelphia, PA.

Brown, C. R., and M. B. Brown. 2005. Between-group transmission dynamics of the swallow bug, Oeciacus vicarius. J. Vector Ecol. 30: 137-143. 
Brown, C. R., and R. A. Sethi. 2002. Mosquito abundance is correlated with cliff swallow (Petrochelidon pyrrhonota) colony size. J. Med. Entomol. 39: 115-120.

Brown, C. R., A. T. Moore, S. A. Knutie, and N. Komar. 2009. Overwintering of infectious Buggy Creek virus (Togaviridae: Alphavirus) in Oeciacus vicarius (Hemiptera: Cimicidae) in North Dakota. J. Med. Entomol. 46: 391394.

Chamberlain, R., and W. D. Sudia. 1961. Mechanism of transmission of viruses by mosquitoes. Annu. Rev. Entomol. 6: 371-390.

Dohm, D. J., and M. J. Turell. 2001. Effect of incubation at overwintering temperatures on the replication of West Nile virus in New York Culex pipiens (Diptera: Culicidae). J. Med. Entomol. 38: 462-464.

Farajollahi, A., W. J. Crans, P. Bryant, B. Wolf, K. L. Burkhalter, M. S. Godsey, S. E. Aspen, and R. S. Nasci. 2005. Detection of West Nile viral RNA from an overwintering pool of Culex pipens pipiens (Diptera: Culicidae) in New Jersey, 2003. J. Med. Entomol. 42: 490-494.

Goddard, L. B., A. E. Roth, W. K. Reisen, and T. W. Scott. 2002. Vector competence of California mosquitoes for West Nile virus. Emerg. Infect. Dis. 8: 1385-1391.

Hayes, C. G. 1989. West Nile fever, pp. 59-88. In T. P. Monath (ed.), The Arboviruses: Epidemiology and Ecology. CRC, Boca Raton, FL.

Hopla, C. E., D. B. Francy, C. H. Calisher, and J. S. Lazuick. 1993. Relationship of cliff swallows, ectoparasites, and an alphavirus in west-central Oklahoma. J. Med. Entomol. 30: 267-272

Hutcheson, H. J., C. H. Gorham, C. Machain-Williams, M. A. Lorono-Pino, A. M. James, N. L. Marlenee, B. Winn, B. J. Beaty, and C. D. Blair. 2005. Experimental transmission of West Nile virus (Flaviviridae: Flavivirus) by Carios capensis ticks from North America. Vector Borne Zoonotic Dis. 5: 293-295.

Komar, N., S. Langevin, S. Hinten, N. Nemeth, E. Edwards, D. Hettler, B. Davis, R. Bowen, and M. Bunning. 2003. Experimental infection of North American birds with the New York 1999 strain of West Nile virus. Emerg. Infect. Dis. 9: 311-322.

Loye, J. 1985. The life history and ecology of the cliff swallow bug, Oeciacus vicarius (Hemiptera: Cimicidae). Cah. ORSTOM Ser. Entomol. Med. Parasitol. 23: 133-139.

Nasci, R. S., H. M. Savage, D. J. White, J. R. Miller, B. C. Cropp, M. S. Godsey, A. J. Kerst, P. Bennett, K. Gottfried, and R. S. Lanciotti. 2001. West Nile virus in overwintering Culex mosquitoes, New York City, 2000. Emerg. Infect. Dis. 7: 742-744.

Oesterle, P. T., N. M. Nemeth, K. VanDalen, H. Sullivan, K. T. Bentler, G. R. Young, R. G. McLean, L. Clark, C. Smeraski, and J. S. Hall. 2009. Experimental infection of cliff swallows (Petrochelidon pyrrhonota) with varying doses of West Nile virus. Am. J. Trop. Med. Hyg. 81: $1159-1164$.

Oesterle, P. T., N. M. Nemeth, G. R. Young, N. L. Mooers, S. Elmore, R. A. Bowen, P. F. Doherty, J. S. Hall, R. G. McLean, and L. Clark. 2010. Cliff swallows, swallow bugs, and West Nile virus: an unlikely transmission mechanism. Vector Borne Zoonotic Dis. 10: 507-513.

Reisen, W. K., Y. Fang, H. D. Lothrop, V. M. Martinez, J. Wilson, P. O'Connor, R. Carney, B. Cahoon-Young, M. Shafii, and A. C. Brault. 2006. Overwintering of West Nile virus in southern California. J. Med. Entomol. 43: 344-355.

Rush, W. A., D. B. Francy, G. C. Smith, and C. B. Cropp. 1980. Transmission of an arbovirus by a member of the family Cimicidae. Ann. Entomol. Soc. Am. 73: 315-318.

Sixl, W., D. Stunzner, and H. D. Withalm. 1989. Serological examinations for antibodies against West Nile virus, Semlikivirus and chikungunyavirus in laboratory mice, parasitized by nidicole fauna from swallow's nests. Geogr. Med. Suppl. 1: 51-55.

Strauss, J. H., and E. G. Strauss. 1994. The alphaviruses: gene-expression, replication, and evolution. Microbiol. Rev. 58: 491-562.

Turell, M. J., M. O'Guinn, and J. Oliver. 2000. Potential for New York mosquitoes to transmit West Nile virus. Am. J. Trop. Med. Hyg. 62: 413-414.

Turell, M. J., M. L. O’Guinn, D. J. Dohm, and J. W. Jones. 2001. Vector competence of North American mosquitoes (Diptera: Culicidae) for West Nile virus. J. Med. Entomol. 38: $130-134$.

Usinger, R. L. 1966. Monograph of Cimicidae (Hemiptera Heteroptera). Entomological Society of America, College Park, MD.

Work, T. H., H. S. Hurlbut, and R. M. Taylor. 1955. Indigenous wild birds of the Nile Delta as potential West Nile virus circulating reservoirs. Am. J. Trop. Med. Hyg. 4: $872-888$

Received 17 February 2010; accepted 18 May 2010. 